\title{
Effects of stone mining on woody plant species diversity and selected soil properties in northern Ethiopia
}

\author{
Leake Belay ${ }^{1}$, Emiru Birhane ${ }^{1 *}$, Amanuel Zenebe ${ }^{1}$, Askal Weldu$^{1}$, Stella Nwawulu Chiemela² \\ and Negasi Solomon ${ }^{1}$
}

\begin{abstract}
Background: Stone mining is one of the main livelihood activities in areas close to major cities in Ethiopia. Mining tends to make a notable impact on woody plant species and soil properties. Information regarding the effect of stone mining on woody plant species diversity and soil properties is limited in Ethiopia. It is also less known how people perceive the impact of stone mining on existing natural resource in the watershed after mining. Therefore, this paper analyzed the effect of stone mining on woody plant species diversity, selected soil properties and perception of nearby community on mining in northern Ethiopia.

Methods: Vegetation and soil sampling were conducted using 6.32 ha sample plots. Samples were randomly selected from mining and adjacent unmined areas. Species abundance, density, basal area, selected soil physical and chemical properties were analyzed. The differences in species diversity and soil physical and chemical properties between the mined and unmined areas were analyzed using independent $t$ test. Household survey was also conducted to assess the view of the local people regarding the effect of mining on ecology.

Results: A total of 35 species representing 19 families in the mining site were recorded while 43 species representing 27 families were recorded in the unmined site. Abundance and density of species were higher in unmined than in mining areas. The most abundant species in the mining and unmined sites were Euclea racemosa subsp. schimperi, Senna singueana, Maytenus arbutifolia, Calpurnia aurea and Buddleja polystachya. Woody species diversity at mining (1.97) was significantly different from that unmined (2.49) site $(p=0.0005)$. Bulk density significantly varied between the mined $\left(1.9 \mathrm{~g} \mathrm{~cm}^{-3}\right)$ and unmined $\left(1.38 \mathrm{~g} \mathrm{~cm}^{-3}\right)$ sites $(p<0.0005)$. Furthermore, significantly higher TN and AvP was recorded at unmined areas as compared to the mining areas $(p<0.05)$. Discussion with communities is mandatory before deciding a site for mining. Respondents argued that mining negatively affects the vegetation and other resources that brought devastating effect on the downstream farms. The communities' were recommended for immediate rehabilitation of abandoned lands to restore it and reduce the negative impact of mining.
\end{abstract}

Conclusions: Stone mining causes an adverse impact on plant species and soil physico-chemical properties. Discussion with communities at the planning stage, immediate restoration activities and monitoring are crucial to reduce the negative impacts of stone mining for further sustainable natural resources development and management.

Keywords: Stone mining, Vegetation, Diversity, Soil properties, Perception, Tigray

\footnotetext{
*Correspondence: emiru.birhane@mu.edu.et

${ }^{1}$ Department of Land Resource Management and Environmental

Protection, Mekelle University, Mekele, Ethiopia

Full list of author information is available at the end of the article
}

\section{Background}

Stone quarrying is an essential industrial sector where stone is mined and produced. Stone mining is the main source of livelihood for many people and play a crucial role in the economic development of many countries. 
However, quarrying tends to make a notable impact on the environment (Gabarrón et al. 2019; Ozcan et al. 2012). The severity of mining is variable depending on size of quarrying area, location and the geological condition of the area.

The extent of the geomorphic impact is a function of the size, number, and the location of the quarry, especially with respect to the overall landscape and the local landforms (Langer 2001). The influence of quarry size on environmental impact is obvious: all other things being equal, the larger the quarry, the larger the geomorphic impact (Sauro 1993). The terrestrial environment is the primary victim of quarry activities, which can be gauged from the denudation of vegetation covers in all the quarry belts (Lameed and Ayodele 2010). Vegetation and soil can be affected at site clearing stage and during off road movement of the trucks. The operation of land clearing led to loss of vegetation cover, soil removal, susceptible geomorphology for erosion, land stability problem where the rock fall on the slope foot and land degradation (Gabarrón et al. 2019; Martínez-Ruiz et al. 2007; Okafor 1988; Sinha et al. 2000). The exploitation of stones, especially through mining activities, are causing huge vegetation losses as a result of large-scale operation, and the abandonment of quarry sites after the stone have become depleted. On the other hand, studies showed that quarry sites can improve biodiversity with careful planning and management. Quarries can also provide a good opportunity to create new habitats or to restore existing ones (Tanko 2007).

In Tigray region, northern Ethiopia stone mining is one of the main sources of livelihoods for many people. During the last decades, there has been phenomenal increase in the mining of foundation and dimension stones, causing large-scale destruction and deterioration to the local habitat of the areas. In Tigray region, deforestation, conversions of land into bare land due to various types of mining activities are frequently noticed. The case is not different in Laelay maychew district, northern Ethiopia where large-scale stone mining is undertaking. Stone mine area in Laelay maychew is mostly in forested area. Harnessing of such resources from these areas starts with clearing of forest and this in turn brings changes in microclimate of the area (Mahato and Pal 2018; Ziaul and $\mathrm{Pal}$ 2016). Therefore, it is important to evaluate the effect of stone mining on vegetation and soil properties for effective and sustainable management of the environment.

Although there have been studies related to environmental and socioeconomic impacts of stone mining across the world (Ako et al. 2014; Darwish et al. 2011; Ming'ate and Mohamed 2016), studies on the effect of stone mining on woody species diversity and soil physical and chemical properties are scanty. There is also a lack of information on how the communities perceive the change in natural resource situation post mining. Therefore, this study assessed the effect of stone mining on woody species diversity, soil physical and chemical properties and the perception of the nearby communities around the mining sites in northern Ethiopia. The results of this study can provide crucial information to policy makers and stakeholders to develop conservation and management strategies.

\section{Materials and methods \\ Description of the study area}

The study was conducted in Laelay Maychew district, central zone of Tigray, Ethiopia (Fig. 1). Geographically, the district is situated at $14^{\circ} 07^{\prime} 00^{\prime \prime}-14^{\circ} 09^{\prime} 20^{\prime \prime} \mathrm{N}$ latitude and $38^{\circ} 38^{\prime} 00^{\prime \prime}$ and $38^{\circ} 49^{\prime} 09^{\prime \prime} \mathrm{E}$ longitude. The site has dry midland and highland agro-climate zone. The total area of the district is $556 \mathrm{~km}^{2}$. The district is characterized by undulating topography on both the northern and east west border of the district, but undulating hills and in pacing mountains altering with plains characterize the central area. The altitude of the study site ranges from 1650 to $2480 \mathrm{~m}$ above sea level. The annual rainfall of the district ranges from 650 to $700 \mathrm{~mm}$. The rainy season usually occurs between June and August, and the growing season varying between 60 and 90 days. The months from April to Jun are the hottest months in the district with average minimum and maximum temperature $12.4{ }^{\circ} \mathrm{C}$ to $29.6{ }^{\circ} \mathrm{C}$, respectively. The coldest month is December where the average minimum and maximum temperature are $8.63^{\circ} \mathrm{C}$ and $26.8^{\circ} \mathrm{C}$.

The study area is dominated by vertisols and cambisols soil types (Hagos 2010). The dominant woody plant species in the area included Vachellia lehi, Faideherbia albida, Vachellia abyssinica, Vachellia etbaica, Euclea racemose subsp. schimperi and Dodonaea viscosa. Major land uses in the study area included cultivated land, forest lands, exclosures and communal grazing lands (WOARD 2011). Exclosures are areas closed from the interference of humans and domestic animals with the goal of promoting plant regeneration of formerly degraded communal grazing lands, often located along steep previous grazing lands (Aerts et al. 2009). The total area under forest in the district is $1783 \mathrm{ha}$, which is $3.3 \%$ of the total area of the district (WOARD 2011).

The livelihood of the households in the study area depends on a mixed crop livestock farming system. The major animal populations were sheep, poultry, cattle, donkey, and camel. Apiculture is a common practice in the study area.

Stone deposition for construction material is found in 15 Kebele of the district. Stones used for foundation 


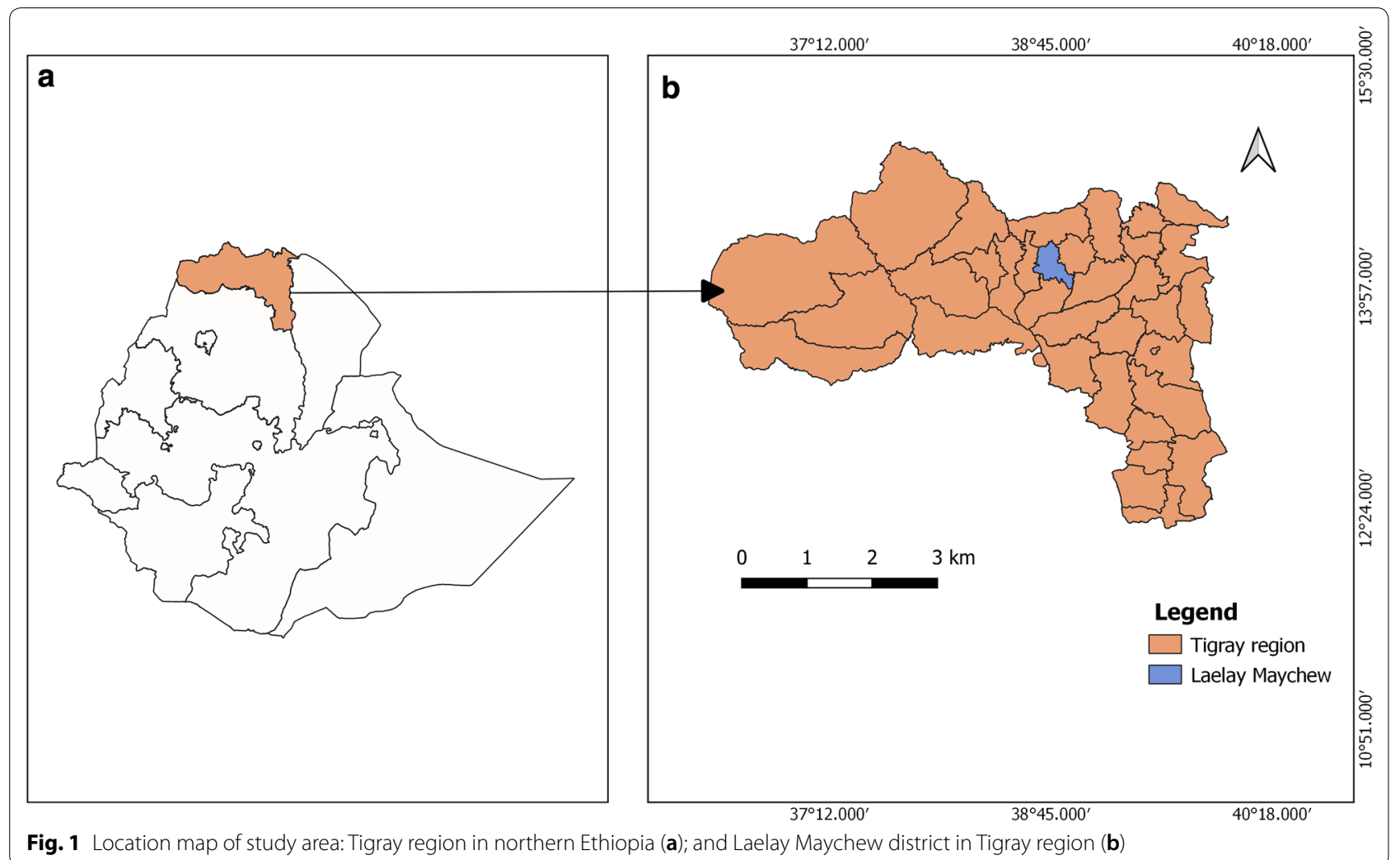

construction were mined from Wolel, Aditsafiee, Dura, Debrebrhan, Seglamen, Modego, Lesaluso, Miha, Hatsebo while stones used for building of houses above foundation were mined in Dereka, Natikablae,
Mahibereselam, Mayweyni, Edagaarbi and Awllo (Table 1). Stone mining have been undertaken for the last 15 years and it was done by both man power and machinery.

Table 1 Eestimated areas covered with stones in Laelay Maychew district. Source: (WOWRED, 2010)

\begin{tabular}{|c|c|c|c|c|}
\hline No & Village & Area of the village $\left(\mathrm{km}^{2}\right)$ & $\begin{array}{l}\text { Estimated area covered with stones } \\
\left(\mathrm{km}^{2}\right)\end{array}$ & Total area (\%) \\
\hline 1 & Mahibereselam & 62.2 & 22.5 & 36 \\
\hline 2 & Awlo & 42.6 & 9.0 & 21 \\
\hline 3 & Aditshafie & 40.7 & 11.2 & 27 \\
\hline 4 & Edaga-arbi & 45.3 & 8.7 & 19 \\
\hline 5 & Mayweynee & 27.1 & 4.2 & 15 \\
\hline 6 & Dereka & 49.6 & 4.5 & 9 \\
\hline 7 & Natka bile & 13.6 & 2.3 & 17 \\
\hline 8 & Modego & 40.1 & 4.5 & 11 \\
\hline 9 & Dura & 25.6 & 8.5 & 33 \\
\hline 10 & Debrebrhan & 13.11 & 0.9 & 7 \\
\hline 11 & Seglamen & 11.2 & 1.4 & 12 \\
\hline 12 & Wollel & 55.9 & 18.4 & 33 \\
\hline 13 & Hatsebo & 43.2 & 3.2 & 7 \\
\hline 14 & Lesalso & 39.7 & 14.5 & 36 \\
\hline 15 & Miha & 27.6 & 11.4 & 41 \\
\hline Total & & 538.3 & 125.3 & 23 \\
\hline
\end{tabular}




\section{Design of the study}

Random sampling was used to select two Kebeles namely Mahibereselam and Dura from the 15 villages known for stone mining. From each selected village, May-gundi and Dura-gobodura watershed were purposely selected. Three parallel line transects with $1 \mathrm{~km}$ distance were laid in each watershed following altitudinal gradient. Along the transect lines, sample plots measuring $20 \mathrm{~m} \times 20 \mathrm{~m}\left(400 \mathrm{~m}^{2}\right)$ were laid down at $50 \mathrm{~m}$ interval from each other. A total of 138 plots were laid of which 69 were in quarry and 69 in non-quarry areas.

\section{Plant inventory}

Trees, shrubs and regenerated seedlings were identfied and recorded from each plot. A botanist supported by the local people was engaged to confirm scientific names and local names of the plant species. Diameters of trees and shrubs were measured at $1.3 \mathrm{~m}$ and $0.3 \mathrm{~m}$ height respectively using diameter tape and caliper. For trees forking below $1.3 \mathrm{~m}$ but above $0.3 \mathrm{~m}$, diameter at stump height (DSH) was measured at $0.3 \mathrm{~m}$ and diameter at breast height $(\mathrm{DBH})$ at $1.3 \mathrm{~m}$. For trees forking below $0.3 \mathrm{~m}$, DSH was measured at $0.3 \mathrm{~m}$ and their $\mathrm{DBH}$ at $1.3 \mathrm{~m}$. For regenerated seedlings (height $<0.5 \mathrm{~m}$ ), only their number was recorded.

\section{Soil sampling}

Soil samples were collected from the four corners and center of each sample plot at a depth of $20 \mathrm{~cm}$ using auger. A composite sample from each plot was taken to analyze the different soil physicochemical properties. For bulk density analysis core sampler was used to collect soil samples. In total 138 (72 May-gundi and 66 Dura-gobodura) soil samples were collected. All samples were placed in paper bags with appropriate labels.

\section{Household survey}

The respondents were sampled randomly in the study area. From a total of 365 households, 120 were sampled from both watersheds. Out of the total sampled respondents, $50 \%$ of the households were quarry beneficiaries $(\mathrm{QB})$ and the rest $50 \%$ were quarry nonbeneficiaries (QNB). Of the total respondents, 18.3\% were female-headed households. Regarding age of the respondents; the total number of respondents with age less than forty-five was 17 and 19 for QB and QNB respectively, likewise 27 respondents in each responding quarry status were between age category forty-five and fifty-five. Concerning level of education of the respondents; illiterates were $30 \%$ and $21.6 \%$ respondents QB and QNB respectively while $26.7 \%$ men in each of the two groups can read and write while 3.3\% and 5\% of females in QB and QNB can read and write respectively.

Data on respondents' perception was collected using questionnaire. The questionnaires were prepared for local resident and relevant government organization to identify the impact of quarry on the socio-economic characteristics and the environment of the inhabitants at the selected watershed.

\section{Data analysis}

Diversity indices were used to analyze the woody species diversity.

Shannon diversity index $(\mathrm{H})$ was calculated using:

$$
\mathrm{H}=-\sum \pi(\operatorname{Ln} \pi)
$$

where, $\pi$ is the proportional abundance of the ith species; $\mathrm{Ln} \pi$ is the natural logarithm of each $\pi$ value.

Species richness (D) was estimated using Mehinicks index (Magurran 1988) as follow.

$$
D=\frac{S}{\sqrt{N}}
$$

where, $\mathrm{S}$ is the number of species; $\mathrm{N}$ is number of individuals in the sample.

Sorenson's measure of similarity $\left(\mathrm{S}_{\mathrm{s}}\right)$ (Magurran 1988) was analyzed using the following formula.

$$
\mathrm{S}_{\mathrm{s}}=\frac{2 \mathrm{a}}{(2 \mathrm{a}+\mathrm{b}+\mathrm{C})}
$$

where, a is number of species common to both quadrats; $\mathrm{b}$ is number of species unique to the first quadrat, and $\mathrm{c}$ is number of species unique to the second quadrat.

Furthermore, basal area (BA) of each woody species was calculated using the following formula as in Kent (2012):

$$
\mathrm{BA}=\frac{\pi \mathrm{D}^{2}}{4}
$$

Importance Value Index (IVI) was computed using the following formula.

$$
\mathrm{IVI}=\mathrm{RD}+\mathrm{RF}+\mathrm{RM}
$$

where, $\mathrm{RD}$ is relative density; RF is relative frequency, and $\mathrm{RM}$ is relative dominance.

Organic carbon $(\mathrm{OC})$ and total nitrogen $(\mathrm{TN})$ were determined using Walkley-Black and Kjeldahl method (Bremner and Mulvaney 1983) respectively. Available phosphorus (AvP) was determined by P-Olsen (Olsen et al. 1982) and potassium (Ex. K) was determined by 
flame photometer methods. $\mathrm{pH}$ and electrical conductivity (EC) were determined using a suspension of 1:5, soils: water ratios. Particle size analyses were determined using the Hydrometer method (Gee and Bauder 1986). In addition, bulk density was determined using core method (Blake and Hartge 1986), drying at $105^{\circ} \mathrm{C}$ for $24 \mathrm{~h}$.

\section{Statistical analysis}

Data were checked for normality using Shapiro-Wilk normality test. The difference in species diversity and soil physical and chemical properties between the quarrying and non-quarry areas were analyzed using independent $\mathrm{t}$ test. SPSS.16 software was used to analyze all the data. Socioecnomic data were analyzed descriptively using frequency, percentage and mean.

\section{Results}

\section{Woody plant species composition}

In total, there were 78 woody plant species and among these, 35 plant species representing 19 families were recorded in the quarry area. The composition of total woody species encountered in the study quadrates were $37 \%, 31.4 \%, 22.8 \%$ and $8.8 \%$ trees, shrubs, bushes and herbs respectively. In the non-quarry area, 43 species were recorded representing 27 families. About 33 species were recorded in common both in the quarry and non-quarry area. The most abundant species in the quarry sites were Euclea racemosa subsp. schimperi, Senna singueana, Maytenus arbutifolia, Calpurnia aurea and Buddleja polystachya. Euclea racemosa subsp. schimperi represented about $36.87 \%$ of the total abundance (Table 2). Similarly, in the non-quarry, Euclea racemosa subsp. Schimperi, Maytenus arbutifolia, Senna singueana, Buddleja polystachya, Calpurnia aurea and Vachellia lehai were the most abundant species. Euclea racemosa subsp. schimperi represented about $35 \%$ of the total abundance.

\section{Woody plant species abundance, basal area and importance value index}

In the study area 1809 and 3268 individuals of woody species were encountered in the quarry and non-quarry areas, respectively (Tables 2,3 ). The densities of woody plants were about 655.5 and 1184 individuals per hectare in the quarry and non-quarry area, respectively (Tables 2 , $3)$. The difference in density of woody species between the two sites was significant $(p<0.05)$. In the quarry area, more than half of the density was contributed by Euclea racemosa subsp. schimperi and Maytenus arbutifolia species. Similarly, in the non-quarry area, more than half of the density was contributed by three species namely Euclea racemosa subsp. schimperi, Maytenus arbutifolia and Buddleja polystachya species. Echinopis hispidus,
Jasmnum abyssinicum Hochst.exDc, Rhamnus staddo, Combretum molle, and Phytolacca dodecandra exhibited very low densities in the non-quarry site.

Basal area (BA) of all woody plants with diameter $>2.5 \mathrm{~cm}$ was $5.29 \mathrm{~m}^{2}$ per hectare for the quarry and $13.18 \mathrm{~m}^{2}$ per hectare for the non-quarry and the difference between the two land managements were significantly different $(\mathrm{p}<0.05)$. The highest basal area proportion for the woody plants was for Euclea racemosa subsp. schimperi in both the quarry and non-quarry site. The basal area for quarry was much influenced by the dominant species (Euclea racemosa subsp. schimperi) that contributed $69.6 \%$ of the total basal area. The basal area of the dominant three species (Euclea racemosa subsp. schimperi, Euphorbia abyssinica and Vachellia lahai) accounts $54.02 \%$ of the total basal area in the non-quarry site. All other species in both land uses had BA $<1 \mathrm{~m}^{2} \mathrm{ha}^{-1}$. About $62.8 \%$ and $38.1 \%$ of the species in the quarry and non-quarry sites respectively had basal area $\leq 0.01 \mathrm{~m}^{2} \mathrm{ha}^{-1}$. In the quarry area, Euclea racemosa subsp. schimperi and Maytenus arbutifolia were found to be the most important species to the local people having 39.7 and 16.4 importance value index, respectively (Table 2). Similarly, Euclea racemosa subsp. schimperi and Maytenus arbutifolia were found to be the most important species to the local people in the non-quarry area having 21.5 and 11.4 importance value index, respectively (Table 3 ).

Figure 2 showed that the basal area for the quarry area were concentrated on 2 to $10 \mathrm{~cm}$ diameter class and significantly decreased with increasing diameter, whereas for the non-quarry most of the basal area was concentrated around 10 to $18 \mathrm{~cm}$ diameter, slightly decreasing to the lower class and significantly decreasing with higher diameter class.

\section{Woody species diversity, richness, evenness and similarity} The average number of individuals per ha for the quarry site was 26.25 while 47.43 was recorded in the nonquarry areas (Table 4). The average number of species was 5.91 and 8.09 for the quarry and non-quarry respectively and significantly different $(\mathrm{p}<0.05)$. Significantly higher Shannon diversity index was recorded in the nonquarry area (2.49) as compared to the quarry area (1.97) $(\mathrm{p}<0.05)$. The Sorenson's similarity index for the quarry and non-quarry was 0.86 .

\section{Soil physical and chemical properties}

Soil bulk density (BD) varied between 1.46 to $2.20 \mathrm{~g} \mathrm{~cm}^{-3}$ with a mean value (Fig. 3) of $1.9 \mathrm{~g} \mathrm{~cm}^{-3}$ for the quarry and 1.2 to $1.66 \mathrm{~g} \mathrm{~cm}^{-3}$ with a mean value of $1.38 \mathrm{~g} \mathrm{~cm}^{-3}$ for the non-quarry (Fig. 3) and the difference was significant $(\mathrm{p}<0.05)$ (Table 5). The soil texture of the quarry 
Table 2 Abundance (AB), density (DE), basal area (BA) and importance value index (IVI) of woody plants in quarry areas

\begin{tabular}{|c|c|c|c|c|c|c|}
\hline Species & Family & Life form & $A B$ (number) & DE (number/ha) & $\mathrm{BA}\left(\mathrm{m}^{2} h \mathrm{a}^{-1}\right)$ & IVI \\
\hline Withania somnifera (L.) & Solanaceae & $\mathrm{SH}$ & 1 & 0.4 & 0 & 0.1 \\
\hline Acokanthera schimperi & Apocynaceae & B & 1 & 0.4 & 0 & 0.1 \\
\hline Euphorbia canderlabrum & Euphorbiaceae & $\mathrm{T}$ & 1 & 0.4 & 0 & 0.1 \\
\hline Euphorbia tirucalli & Euphorbiaceae & $\mathrm{T}$ & 1 & 0.4 & 0 & 0.12 \\
\hline Psydrax schimperiana & Rubiaceae & $\mathrm{T}$ & 1 & 0.4 & 0 & 0.11 \\
\hline Bridelia micrantha & Euphorbiaceae & $\mathrm{T}$ & 1 & 0.4 & 0 & 0.11 \\
\hline Clematis simensis Fres. & Ranunculaceae & WH & 1 & 0.4 & 0 & 0.1 \\
\hline Ziziphus spina-christi & Rhamanaceae & $\mathrm{T}$ & 1 & 0.4 & 0 & 0.11 \\
\hline Grewia ferruginea & Tiliaceae & B & 2 & 0.7 & 0 & 0.22 \\
\hline Vachellia bussei & Fabaceae & $\mathrm{T}$ & 2 & 0.7 & 0 & 0.2 \\
\hline Alendiya & Unidentified & $B$ & 2 & 0.7 & 0 & 0.2 \\
\hline Rumexnervosus & Polygonaceae & $\mathrm{SH}$ & 2 & 0.7 & 0 & 0.2 \\
\hline Bridelia micrantha & Euphorbiaceae & $\mathrm{T}$ & 3 & 1.1 & 0.06 & 0.57 \\
\hline Phytolacca dodecandra & Phytolaccaceae & B & 3 & 1.1 & 0.01 & 0.37 \\
\hline Albizia scimgeriana & Fabaceae & B & 4 & 1.4 & 0 & 0.33 \\
\hline Maytenus senegalensis (Lam.) & Celastraceae & $\mathrm{S} / \mathrm{T}$ & 4 & 1.4 & 0 & 0.41 \\
\hline Murkus_zbi & Unidentified & $\mathrm{SH}$ & 4 & 1.4 & 0.05 & 0.49 \\
\hline Dicrostachys cinerea & Mimosaceae & $\mathrm{SH}$ & 5 & 1.8 & 0 & 0.28 \\
\hline Entada abyssinica & Mimosaceae & B & 5 & 1.8 & 0 & 0.35 \\
\hline Vachellia abysinica Hochst.exBenth & Fabaceae & T & 6 & 2.2 & 0.03 & 0.48 \\
\hline Acacia saligna & Mimosaceae & $\mathrm{T}$ & 6 & 2.2 & 0.08 & 1.18 \\
\hline Faidherbia albida & Fabaceae & T & 9 & 3.3 & 0.06 & 0.95 \\
\hline Solanum incanum L. & Solanaceae & B & 12 & 4.3 & 0.01 & 0.98 \\
\hline Rumexnervosus & Polygonaceae & B & 17 & 6.2 & 0.01 & 1.27 \\
\hline Dodonea angustifolia (L.) Jack & Sapindaceae & $\mathrm{SH}$ & 18 & 6.5 & 0.01 & 1.42 \\
\hline Vachellia etbaica Schlueinf & Mimosaceae & $\mathrm{T}$ & 21 & 7.6 & 0.08 & 2.17 \\
\hline Vachellia lehai & Fabaceae & $\mathrm{T}$ & 28 & 10.1 & 0.2 & 2.76 \\
\hline Aloe berhana Tad. & Aloaceae & WH & 28 & 10.1 & 0 & 2.8 \\
\hline Rhoicissus tridentata & Vitaceae & WH & 29 & 10.5 & 0.01 & 2.96 \\
\hline Croton macrostachyus & Euphorbiaceae & $\mathrm{T}$ & 36 & 13 & 0.04 & 3.11 \\
\hline Buddleja polystachya & Lndigenous & $\mathrm{SH}$ & 106 & 38.4 & 0.11 & 4.7 \\
\hline Calpurnia aurea (Alt.) & Fabaceae & $\mathrm{SH}$ & 111 & 40.2 & 0.12 & 5.29 \\
\hline Senna singueana (Del.) Lack & Caesalpiniodeae & $\mathrm{SH}$ & 205 & 74.3 & 0.22 & 9.26 \\
\hline Maytenus arbutifolia (A. Rich.) & Celastraceae & $\mathrm{SH}$ & 466 & 168.8 & 0.49 & 16.44 \\
\hline Euclea racemosa subsp.schimperi & Ebenaceae & $\mathrm{SH}$ & 667 & 241.7 & 3.68 & 39.76 \\
\hline Total & & & 1809 & 655.4 & 5.29 & 100 \\
\hline
\end{tabular}

$T$ Tree, SH Shrub, B Bush, WH Woody herb

were sandy loam $16.7 \%$, silt loam $16.7 \%$, sandy clay loam $33.3 \%$, and clay loam $33.3 \%$; and similarly silt loam $16.7 \%$, loamy texture $33.3 \%$ and clay $50 \%$ for the non-quarry site.

The two sites showed a significant difference in TN and $\operatorname{AvP}(\mathrm{p}<0.05)$, and higher value were accounted to the non-quarry area. In contrast the $\mathrm{pH}$ value was relatively higher in soils of quarry compared to non-quarry area and this was significant $(\mathrm{p}<0.05)($ Table 5). Soil $\mathrm{pH}$ result indicates, the soils of the quarry was $66.7 \%$ alkaline and the rest $33.3 \%$ very alkaline, whereas soil of the non-quarry was $16.67 \%$ neutral and $83.33 \%$ lie on alkaline soil. However, there were no significant differences on $\mathrm{AvK}, \mathrm{OC}$ and $\mathrm{EC}$ between the quarry and non-quarry areas.

\section{Community perception regarding quarry}

Regarding historical background of the quarry area, $86.7 \%$ responded that, the quarry areas were covered with different vegetation of bushes, shrubs, and trees. Among the total respondents, $43.3 \%$ and $32.5 \%$ believed 
Table 3 Abundance (AB), density (DE), basal area (BA) and Importance Value Index (IVI) of woody plants in non-quarry areas

\begin{tabular}{|c|c|c|c|c|c|c|}
\hline Species & Family & Life form & $A B$ (number) & $\mathrm{DE}$ (number/ha) & $B A\left(m^{2} h a^{-1}\right)$ & IVI \\
\hline Jasmnum abyssinicum Hochst.exDc & Oleaceae & $\mathrm{SH}$ & 1 & 0.4 & 0 & 0.08 \\
\hline Rhamnus staddo & Anacardiaceae & $\mathrm{T}$ & 1 & 0.4 & 0 & 0.08 \\
\hline Phytolacca dodecandra & Phytolaccaceae & T & 1 & 0.4 & 0 & 0.08 \\
\hline Combretum molle & Combretaceae & $\mathrm{T}$ & 1 & 0.4 & 0.18 & 0.53 \\
\hline Plumbago zeylanica & Unidentified & B & 2 & 0.7 & 0 & 0.15 \\
\hline Maesa lanceolata & Myrsinaceae & $\mathrm{T}$ & 2 & 0.7 & 0.01 & 0.17 \\
\hline Solanum incanum $L$. & Solanaceae & B & 3 & 1.1 & 0 & 0.16 \\
\hline Ziziphus spin-christi (L.) Desf. & Rhamanaceae & T & 3 & 1.1 & 0.01 & 0.18 \\
\hline Bcium gradflorum & Lamiaceae & B & 4 & 1.4 & 0 & 0.18 \\
\hline Sunuh & Unidentified & B & 4 & 1.4 & 0 & 0.25 \\
\hline Rhus natalensis & Anacardiaceae & $\mathrm{SH}$ & 6 & 2.2 & 0 & 0.27 \\
\hline Justicia schimperiana & Acanthaceae & $\mathrm{SH}$ & 6 & 2.2 & 0.01 & 0.42 \\
\hline Echinopis hispidus O.hoffm & Asteraceae & WH & 7 & 2.5 & 0 & 0.55 \\
\hline Withania somnifera (L.) & Solanaceae & $\mathrm{SH}$ & 7 & 2.5 & 0 & 0.48 \\
\hline Clerodendron myricoides(Hochst) R.Br ex Vatke & Verbenaceae & $\mathrm{SH}$ & 7 & 2.5 & 0.01 & 0.36 \\
\hline Acacia saligna (Labill.) Wendel. & Fabaceae & T & 9 & 3.3 & 0.19 & 0.84 \\
\hline Maerua angolensis DC. Subsp. & Capperidaceae & $\mathrm{T}$ & 9 & 3.3 & 0.02 & 0.54 \\
\hline Murkus_zbie & Unidentified & B & 10 & 3.6 & 0.03 & 0.5 \\
\hline Maytenus senegalensis (Lam.) Exell & Celastraceae & $\mathrm{S} / \mathrm{T}$ & 13 & 4.7 & 0.73 & 2.52 \\
\hline Carrisa edulis Vahl. & Apocynacea & $\mathrm{T}$ & 14 & 5.1 & 0.01 & 0.51 \\
\hline Grewia ferruginea A.Rich & Tiliaceae & B & 17 & 6.2 & 0.02 & 0.49 \\
\hline Dicrostachys cinerea & Fabaceae & $\mathrm{SH}$ & 18 & 6.5 & 0.03 & 1.06 \\
\hline Alediya & Unidentified & B & 20 & 7.2 & 0.02 & 1.18 \\
\hline Entada abyssinica & Mimosaceae & B & 20 & 7.2 & 0.01 & 1.02 \\
\hline Vachellia etbaica Schlueinf. & Mimosideae & T & 24 & 8.7 & 0.17 & 0.95 \\
\hline Euphorbia canderlabrum & Euphorbiaceae & T & 24 & 8.7 & 2.36 & 6.99 \\
\hline Acokanthera schimperi & Apocynaceae & $B$ & 28 & 10.1 & 0.15 & 1.27 \\
\hline Aloe berhana Tad. & Aloaceae & WH & 29 & 10.5 & 0.01 & 1.33 \\
\hline Rumexnervosus & Polygonaceae & B & 29 & 10.5 & 0.09 & 1.33 \\
\hline Rhoicissus tridentata & Vitaceae & WH & 35 & 12.7 & 0.03 & 1.44 \\
\hline Dodonea angustifolia (L.) Jack & Sapindaceae & $\mathrm{SH}$ & 38 & 13.8 & 0.02 & 1.64 \\
\hline Albizia scimgeriana & Fabaceae & B & 39 & 14.1 & 0.02 & 1.11 \\
\hline Faidherbia albida & Fabaceae & $\mathrm{T}$ & 51 & 18.5 & 0.68 & 3.23 \\
\hline Psydrax schimp eriana & Rubiaceae & T & 59 & 21.4 & 0.23 & 1.99 \\
\hline Croton machostachys & Euphorbiaceae & $\mathrm{T}$ & 74 & 26.8 & 0.43 & 3.29 \\
\hline Vachellia abysinica Hochst.ex Benth. & Fabaceae & T & 105 & 38 & 0.59 & 3.74 \\
\hline Vachellia lehai & Fabaceae & $\mathrm{T}$ & 183 & 66.3 & 1.03 & 6.73 \\
\hline Calpurnia aurea(Alt.) & Fabaceae & $\mathrm{SH}$ & 277 & 100.4 & 0.43 & 5.56 \\
\hline Senna singueana (Del.) Lack. & Caesalpiniodeae & $\mathrm{SH}$ & 311 & 112.7 & 0.47 & 7.75 \\
\hline Buddleja polystachya & Lndigenous & $\mathrm{SH}$ & 328 & 118.8 & 0.53 & 6.15 \\
\hline Maytenus arbutifolia (A. Rich.) Wilczek. & Celastraceae & $\mathrm{SH}$ & 591 & 214.1 & 0.93 & 11.43 \\
\hline Euclea racemosa subsp. schimperi & Ebenaceae & $\mathrm{SH}$ & 858 & 310.9 & 3.77 & 21.51 \\
\hline Total & & & 3268 & 1184 & 13.18 & 100.2 \\
\hline
\end{tabular}

TTree, SH Shrub, B Bush, WH Woody herb

that government and individuals respectively decided the area to be quarried. Among the respondents, $44.8 \%$ thought that, the responsible body did not involve the communities on the decisions of the areas for mining. Majority (72\%) of the respondents opined that the causes of vegetation loss resulted from land use practices such 


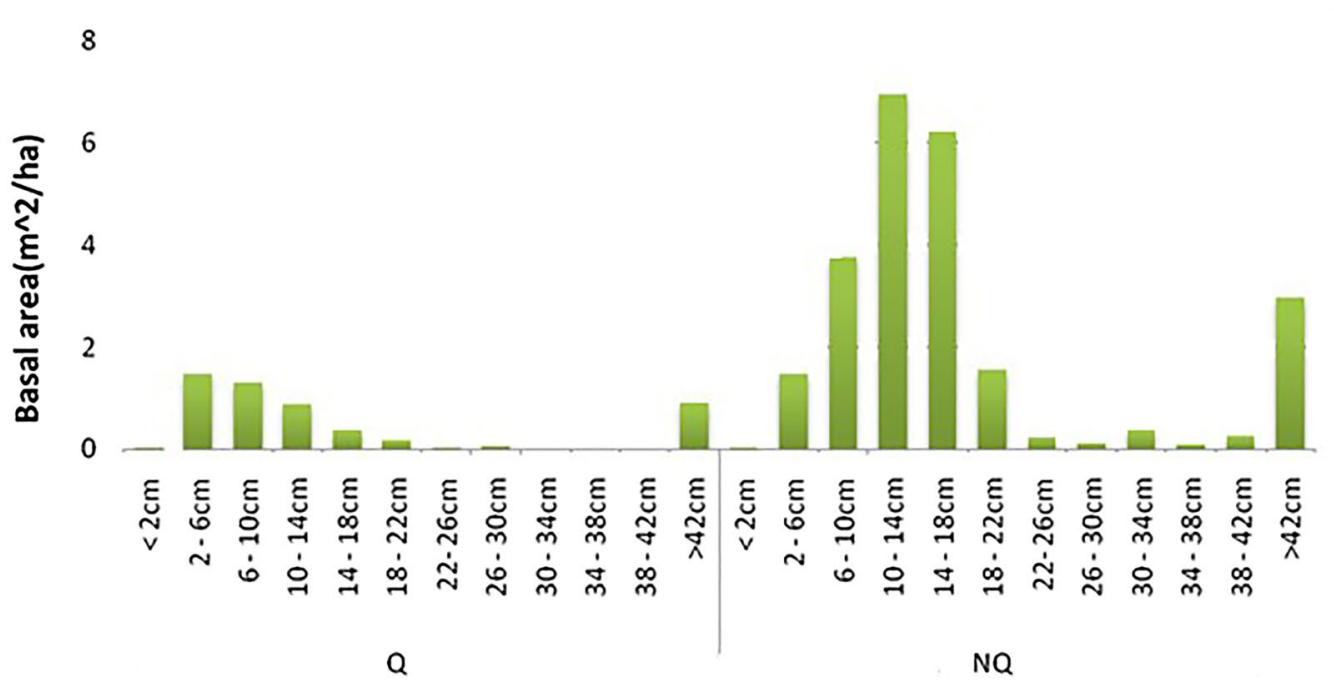

Diameter Classes

Fig. 2 Basal area $\left(\mathrm{m}^{2} \mathrm{ha}^{-1}\right)$ of quarry $(\mathrm{Q})$ and non-quarry $(\mathrm{NQ})$ for a given diameter class

Table 4 Diversity of woody species across quarry and nonquarry areas

\begin{tabular}{llllll}
\hline Variable & \multicolumn{2}{l}{ Mean values } & t value & p value \\
\cline { 2 - 4 } & \multicolumn{2}{c}{ Quarry } & Non quarry & & \\
\hline $\begin{array}{l}\text { Number of individuals } \\
\text { per ha }\end{array}$ & 655.5 & 1184 & $-7.182^{* *}$ & 0.000 \\
$\begin{array}{l}\text { Species richness } \\
\text { Shannon diversity }\left(H^{\prime}\right)\end{array}$ & 5.91 & 8.09 & $-4.620^{* *}$ & 0.000 \\
\hline
\end{tabular}

$\left({ }^{*} p<0.05 ; * * p<0.01\right)$

as; mining, overgrazing, deforestation and generally poor land management. All the sampled respondents believed that quarry has both negative and positive impact in the study areas. In addition, most of the respondents mentioned that, due to quarry activities, tremendous vegetation were lost and the area is now becoming a source of floods and exacerbating erosion. Fifty-six percent of the respondents thought that the vegetation loss in the quarry were mostly as consequences of mining activity. Regarding species endangered and extinction, about $51 \%$ of the respondents indicated that species like Faidherbia albida, Vachellia abyssinica, Dodonea angustifolia and Entada abyssinica were endangered from the quarry areas. Likewise, the survey showed that, stone mining was evaluated by $56.6 \%$ of the respondents to have negative impact on cultivated land while $43.4 \%$ of the respondents evaluated, the role of stone mining on cultivated land as positive.

Almost all the respondents thought that the abandoned quarry areas were not being rehabilitated (Fig. 4) and about $50 \%$ of the respondents indicated that this was due to lack of responsibility of relevant government office. Yet, all of the respondents responded that it is possible to rehabilitate the badly degraded lands and make them productive again with careful planning and management. Besides, they recommended closing areas from the interference of human beings and livestock supported by soil and water conservation measures to increase the amount of water infiltrating into the soil.

\section{Discussion}

\section{Effects of stone mining on woody species diversity} and density

In the present study, significantly lower species richness and Shannon diversity index was recorded in the quarry areas as compared to the non-quarry area. In line with this study, Wheater and Cullen (1997) found lower number of plant species and diversity in Disused quarries as compared to natural Daleside in Derbyshire, United Kingdom. Meaza et al. (2017) also reported that woody species encountered at plot level decreased from artisanal gold mined to unmined sites. They also revealed that dead trees and exposed tree roots were higher in mined than the unmined areas which might discourage regeneration and recruitment of woody vegetation.

The species richness, diversity and composition of woody species in an area depend largely on anthropogenic effects. Stone mining is among the destructive anthropogenic activities on natural resources. For example, Akanwa et al. (2017) revealed that quarrying 


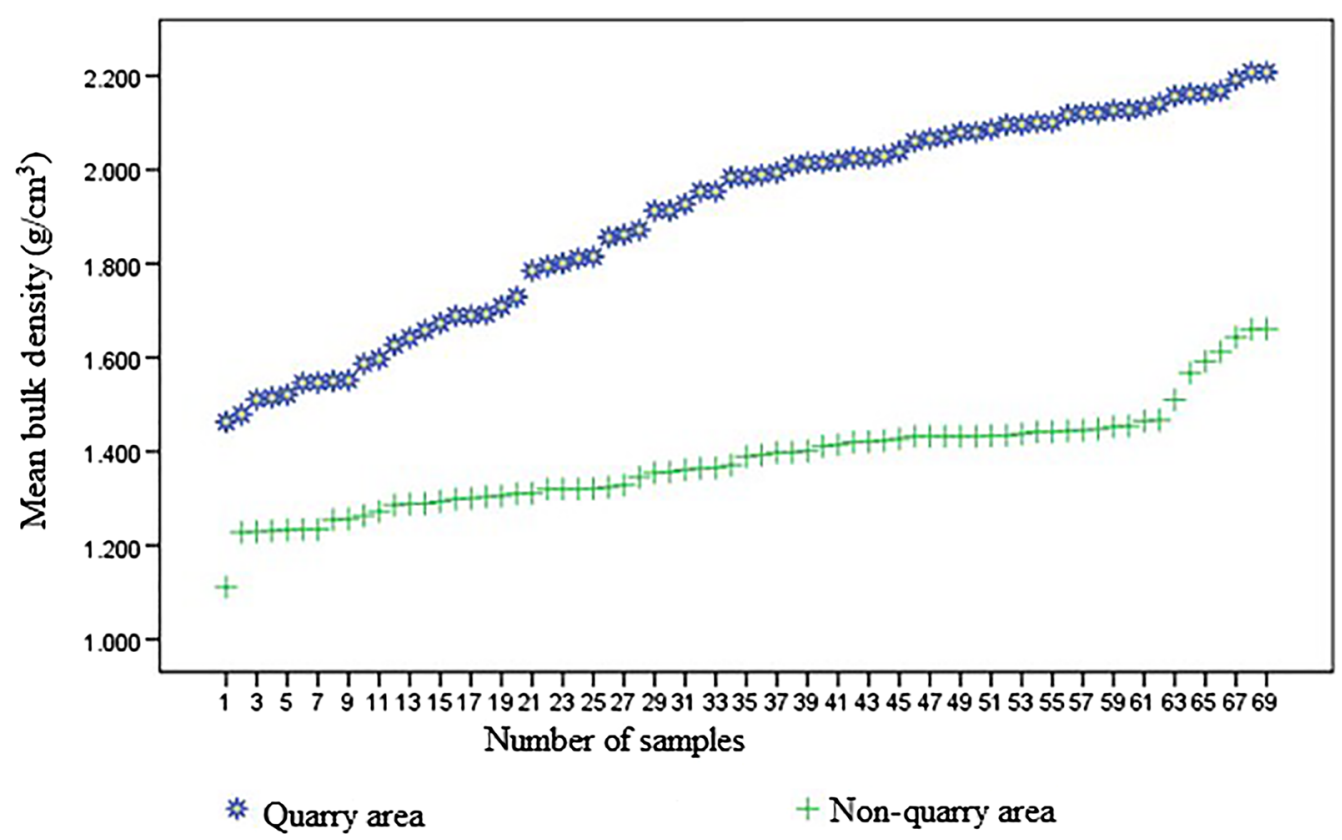

Fig. 3 Soil bulk density of quarry and non-quarry areas

Table 5 Soil chemical and physical pparameters on Quarry and Non-quarry areas

\begin{tabular}{lllll}
\hline Variable & \multicolumn{2}{l}{ Land use types } & t value & p value \\
\cline { 2 - 3 } & Quarry & Non-quarry & & \\
\hline Mean TN (\%) & 0.091 & 0.1493 & -0.058250 & 0.000 \\
Mean AvP $(p p m)$ & 3.867 & 6.4233 & -2.611667 & 0.027 \\
Mean EX. K (ppm) & 253.1 & 316.29 & -1.778000 & 0.127 \\
Mean OC (\%) & 1.670 & 1.5883 & 0.5520000 & 0.013 \\
Mean EC (ds/m) & 1.288 & 0.6233 & 0.6650000 & 0.071 \\
Mean pH & 8.282 & 7.7120 & 0.5700000 & 0.005 \\
Mean BD $\left(\mathrm{g} / \mathrm{cm}^{3}\right)$ & 1.903 & 1.3801 & 17.463000 & 0.000 \\
\hline
\end{tabular}

practices have destroyed arable lands, economic trees and forests in Ebonyi State, Nigeria. Stone mining can affect biodiversity by disturbing plant growth by settling on leaves and hinder photosynthesis thus disrupting food chains (Akanwa et al. 2017; Gabarrón et al. 2019).

Furthermore, in this study, the quarry area had onethird of total plant density compared to that of the nonquarry areas. In line with this study, Letheren (2008) in their research on the comparison of woody vegetation species abundance on quarry surrounding and reference area found that highest abundance in the reference area as compared to the quarry areas. Meaza et al. (2017) also reported that tree densities of mined (990 per ha) were significantly lower than the unmined sites
(2373 per ha). This could be probably due to higher soil bulk density, low moisture conditions, ability to tolerate low nutrient levels and lower species adaptations to the harsh physical nature of the substrate. Low nutrient habitats are usually colonizing with low relative growth rates. These adaptations enable colonizing to maximize the nutrient uptake and ensure high nutrient use efficiency in low nutrient environment (Lameed and Ayodele 2010). Furthermore, the waste materials that remain after the extraction of the stone are dumped on the surrounding land, thus causing loss of topsoil, nutrients and supportive microflora and vegetation (Hammond 1988; Singh et al. 2002).

\section{Effects of quarrying on soil physical and chemical properties}

The soil bulk density of quarry area was significantly higher than the non-quarry sites. In line with the present study Shrestha and Lal (2008) found higher bulk density in mining areas. The higher soil bulk density value of quarry area could be attributed to overload of soil, stone fragments, and boulders produced during the mining from the quarry pits, and due to track load movement. Similar results also showed in Spain by Jordan et al. (2012). Gabarrón et al. (2019) also revealed that mining altered important soil properties such as increasing bulk density. The change in bulk density affects soil hydraulic properties and hydrological stability which in turn influences soil remediation. Furthermore, compacted mine 

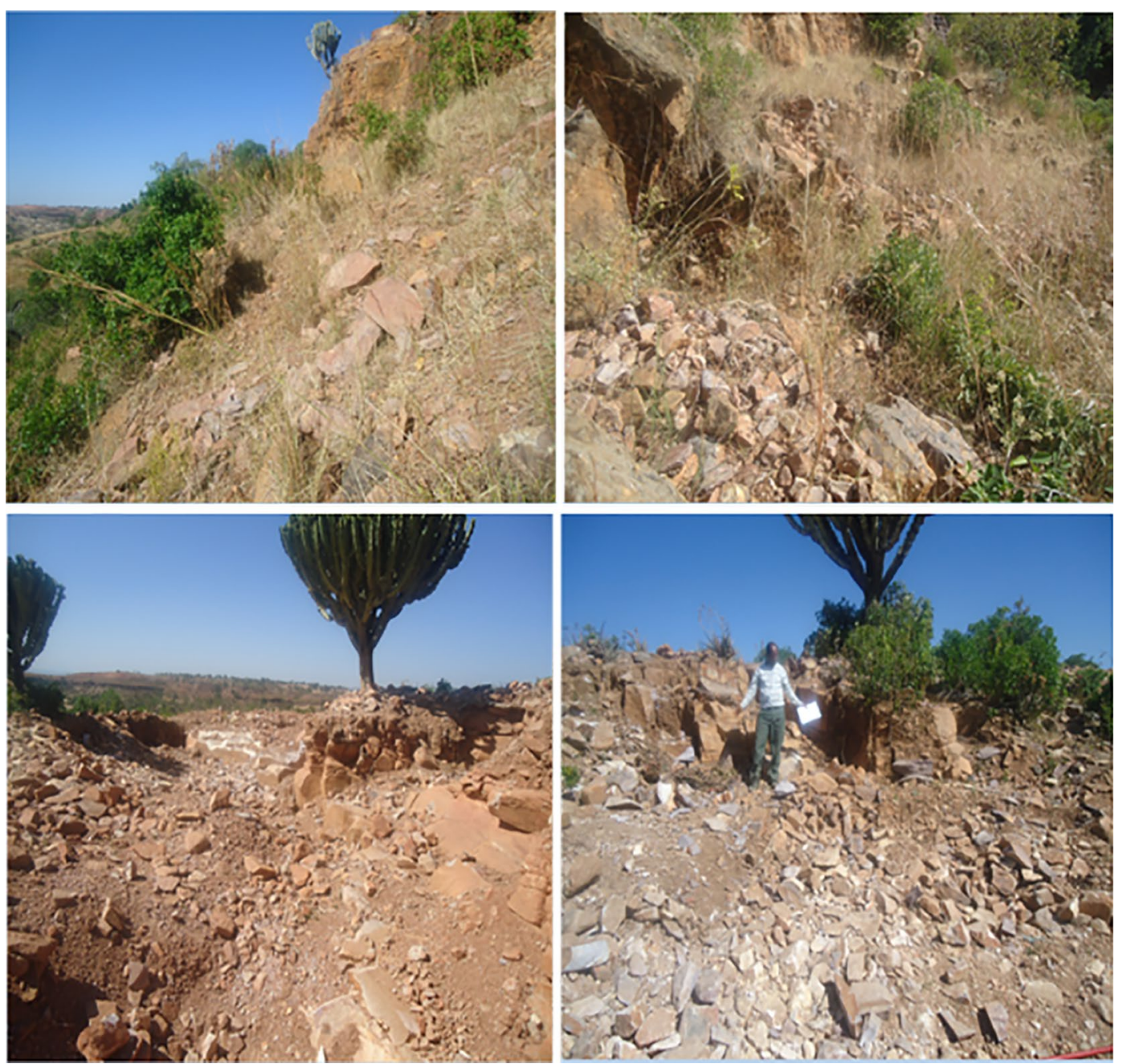

Fig. 4 Quarry areas in May-gundi watershed

soils prevent seed germination and the establishment of native vegetation.

When mining removes the vegetation and inevitably leads to the loss of some plant nutrients from the site and altered the nutrient balance of the site. In the present study, lower total nitrogen and available phosphorus was recorded in the quarry area as compared to the non-quarry area. Several authors have also documented the effects of mining on certain soil chemical properties (Shrestha and Lal 2011; Zhen et al. 2017). For example, Shrestha and Lal (2011) indicated that mining and reclamation activities decreased soil organic carbon (SOC) and nitrogen (N) pools in Ohio. Similarly, Assel (2006) found a lower and reduced content of soil $\mathrm{N}$ and $\mathrm{P}$ in mine soils when compared to the natural forest, which was due to ecosystem disruption, removal of vegetation and loss of litter layer during mineral mining. Besides, Hilson (2001) argued that regardless of the overburden type used, plant available $\mathrm{N}$ and $\mathrm{P}$ tend to be low in mined soils, which may limit plant growth. Sheoran et al. (2010) also added that the consequences of physical disturbance to the topsoil during stripping, stockpiling and reinstatement, cause unusually large $\mathrm{N}$ transformations and movements eventually leading to a substantial loss in soil fertility and productivity.

The lower total nitrogen in quarry as compared to non-quarry might be due to low litter input and low cover of good fertility potential tree species like Faidherbia albida (Melaku 2007). However, in the nonquarry area the availability of dense forest could increase litter inputs. Similarly, the lower available phosphorus in the quarry area might be attributed to the medium $\mathrm{pH}$ available in the soil that hinders phosphorus availability.

On the other hand, the higher mean value of $\mathrm{pH}$ found in the quarry area than non-quarry could be due to 
weathering accessibility of basic cations from the quarryextracted stones. According to Machin and Navas (2000) soil $\mathrm{pH}$ can increase in mining areas where alkaline materials are processed, especially surrounding magnesite calcination plants, where the $\mathrm{pH}$ can increase up to maximum values of 9.5. In contrary to the present study, Kalu and Ogbonna (2019) reported lower $\mathrm{pH}$ value at the edge of quarry site in Akpoha and Ishiagu communities of Ebonyi state, Nigeria.

The results of percentage of OC, Ex, $\mathrm{K}$ and EC showed non-significant difference between the quarry and non-quarry areas. This could be due to the activity that has been implemented by the stone extractors for better crushing of hard stones the extractors were burning the stones with woods, cow dung, and crop residue and this could add some types of nutrients to the soil of the quarry area. Therefore, the losses of some types of nutrients that has been created by quarry activity could be balanced. In contrary to the present study, lower organic carbon was recorded at the edge of the quarry site as compared to the control Akpoha and Ishiagu communities of Ebonyi state, Nigeria (Kalu and Ogbonna 2019).

\section{Community perception on the impact of quarry}

Views gathered from respondents in the study area revealed that loss of vegetation and soil erosion have been the most important negative effects of quarry. Removal of vegetative cover usually takes place intentionally in order to access the stone. In May-Gundi watershed, AdiSendel quarry site is a clear example of such removal of vegetation. These activities significantly contribute to erosion and loss of fauna around the quarry area. Since most quarrying do not preserve the topsoil removed before excavation begins, the topsoil is often washed away into surface water, carrying with it ecologically valuable seed banks that are necessary for the regeneration of vegetation.

In addition, most of the respondents specify that, loss of economically important woody species such as Faidherbia albida, Vachellia abyssinica, Dodonea angustifolia and Entada abyssinica has been one tremendous drawback of stone quarrying in the study area. The Faidherbia albida trees that are also called Acacia albida are not cultivated but grow in the wild. These trees had been endangered due to quarrying and as result of this soil fertility, animal feed and household material benefits are not possible and consequent in reduction in household income.

Respondents also thought that quarry areas were selected and allocated without the participation of the community. This could be attributed by the misunderstanding between the local experts and communities in understanding the decision-making hierarchy of representative democracy. The experts in collaboration with village local administrators allocated the proposed quarry sites to individuals and/or group of individuals witout informing the community. The decision making gap creates the community to feel lack of responsibility in the managment and control of their surrounding natural resources. Even though, the quarry sector has adversely impacted the natural resources around the quarry area, most of the respondents believed that, the quarryimpacted area including the abandon quarry area would possibly rehabilitate. Among the measures suggested for rehabilitation are; assignment of specified buffer zone between the quarry area and other land use, mining system instead of expanding its horizontal attention should be given vertical, possibly the stone mining should first be given to the youngsters that do not have their own cultivable land, and the rehabilitating of quarry area should be strengthened with soil and water conservation measures and replanting tree species.

\section{Conclusions}

Stone mining significantly affected woody species diversity and selected soil properties. Stone mining showed a negative impact in both density as well as diversity of woody species. Significantly lower Shannon diversity, species richness and abundance were found in the quarry areas as compared to the non-quarry areas. Significantly lower available nitrogen and phosphorus was recorded in the quarry areas as compared to nonquarry areas. However, higher value of bulk density, $\mathrm{OC}$ and $\mathrm{pH}$ was found in quarry than non-quarry areas. Comparatively, the chemical result indicates lower fertility for the quarry than non-quarry. Almost all of the respondents are aware of the impact of quarry on vegetation and soil properties. However, though the community understands the negative impacts of quarry, remedial actions have not yet been conducted individually as well as collectively. Therefore, attention should be given by all relevant stakeholders in minimizing the negative impacts of quarry for further sustainable natural resources development.

\footnotetext{
Abbreviations

AvP: Available phosphorus; BA: Basal area; BD: Bulk density; DBH: Diameter at breast height; IVI: Important value index; TN: Total nitrogen; OC: Organic carbon; WOANRD: Woreda office of agriculture \& natural rsource development; WOWED: Woreda of water, energy \& development.

\section{Acknowledgements}

We are grateful to the College of Dry Land Agriculture and Natural Resources Department of Land Resources Management and Environmental Protection for financially supporting this research. We are also grateful to the two anonymous referees for constructive comments on an earlier version of this manuscript.
} 


\section{Authors' contributions}

LB conceptualizes the study, analyze and interpret the data. AW and NS wrote the manuscript. EB, AZ, SN and NS revised and edited the manuscript. All authors read and approved the final manuscript.

\section{Funding}

No fund.

\section{Availability of data and materials}

All data generated or analyzed during this study are included in the manuscript.

\section{Ethics approval and consent to participate}

Not applicable.

\section{Consent for publication}

Not applicable.

\section{Competing interests}

The authors declare that they have no competing interests.

\section{Author details}

${ }^{1}$ Department of Land Resource Management and Environmental Protection, Mekelle University, Mekele, Ethiopia. ${ }^{2}$ Department of Agricultural Economics, University of Nigeria, Nsukka, Enugu, Nigeria.

Received: 4 December 2019 Accepted: 8 May 2020

Published online: 10 June 2020

\section{References}

Aerts R, Nyssen J, Haile M (2009) On the difference between "exclosures" and "enclosures" in ecology and the environment. J Arid Environ 73(8):762-763

Akanwa AO, Okeke FI, Nnodu VC, lortyom ET (2017) Quarrying and its effect on vegetation cover for a sustainable development using high-resolution satellite image and GIS. Environ Earth Sci 76(14):505. https://doi. org/10.1007/s12665-017-6844-x

Ako TA, Onoduku US, Oke SA, Essien BI, Idris FN, Umar AN, Ahmed AA (2014) Environmental effects of sand and gravel mining on land and soil in Luku, Minna, Niger State, North Central Nigeria. J Geosci Geomat 2(2):42-49

Assel P (2006) Evaluating the usefulness of Acacia auriculiformis in ameliorating surface mine degraded lands. Unpublished B. Sc. dissertation, Department of Agroforestry, Kwame Nkrumah University of Science and Technology, Kumasi, Ghana, 1-24

Blake GR, Hartge K (1986) Bulk density. Methods Soil Anal. 5:363-375

Bremner JM, Mulvaney C (1983) Nitrogen—total. Methods Soil Anal. 9:595-624

Darwish T, Khater C, Jomaa I, Stehouwer R, Shaban A, Hamzé M (2011) Environmental impact of quarries on natural resources in Lebanon. Land Degrad Dev 22(3):345-358. https://doi.org/10.1002//dr.1011

Gabarrón M, Zornoza R, Acosta JA, Faz Á, Martínez-Martínez S (2019) Chapter Five-Mining environments. In: Pereira P (ed) Advances in Chemical Pollution, Environmental Management and Protection, vol 4. Elsevier, Amsterdam, pp 157-205

Gee GW, Bauder JW (1986) Particle-size analysis. Methods Soil Anal. 5:383-411 Hagos T (2010) The choice of Aksum as a metropolis. Annales d'Éthiopie, 139-156 Hammond AA (1988) Mining and quarrying wastes: a critical review. Eng Geol 25(1):17-31. https://doi.org/10.1016/0013-7952(88)90016-6

Hilson G (2001) A contextual review of the Ghanaian small-scale mining industry. Mining, Minerals and Sustainable Development, 76

Jordan M, Garcia-Orenes F, Mataix-Solera J, Garcia-Sanchez E (2012) Evaluation of the physical properties, bulk density and aggregate stability of potential substrates in quarry restoration. Paper presented at the EGU General Assembly Conference Abstracts

Kalu IE, Ogbonna NJ (2019) Investigation of environmental effect of stone quarrying activities on soil and water in Akpoha and Ishiagu communities of Ebonyi state, Nigeria. Int J Construct Manag. https://doi org/10.1080/15623599.2019.1604115

Kent M (2012) Vegetation description and data analysis: a practical approach. Wiley-Blackwell, Hoboken
Lameed G, Ayodele A (2010) Effect of quarrying activity on biodiversity: case study of Ogbere site, Ogun State Nigeria. Afr J Environ Sci Technol 4(11):740-750

Langer WH (2001) Potential environmental impacts of quarrying stone in karst: a literature review. Citeseer, Princeton

Letheren B (2008) Planning the rehabilitation of a sandstone quarry in Rajasthan. Citeseer, Princeton

Machin J, Navas A (2000) Soil pH changes induced by contamination by magnesium oxides dust. Land Degrad Dev 11(1):37-50

Magurran AE (1988) Ecological diversity and its measurement. Princeton University Press, Princeton

Mahato S, Pal S (2018) Changing land surface temperature of a rural Rarh tract river basin of India. Remote Sens Appl 10:209-223. https://doi. org/10.1016/j.rsase.2018.04.005

Martínez-Ruiz C, Fernández-Santos B, Putwain PD, Fernández-Gómez MJ (2007) Natural and man-induced revegetation on mining wastes: changes in the floristic composition during early succession. Ecol Eng 30(3):286-294. https://doi.org/10.1016/j.ecoleng.2007.01.014

Meaza H, Ali M, Tesfamariam Z, Abebe N (2017) Impacts of artisanal gold mining systems on soil and woody vegetation in the semi-arid environment of northern Ethiopia. Singap J Trop Geogr 38(3):386-401. https://doi. org/10.1111/sjtg.12203

Melaku E (2007) Impact assessment and restoration of quarry site in urban environment: the case of Augusta quarry. Addis Ababa University, Addis Ababa

Ming'ate FLM, Mohamed. MY (2016) Impact of stone quarrying on the environment and the livelihood of communities in Mandera County, Kenya. J Sci Res Rep 10:1-9

Okafor FC (1988) Rural development and the environment: degradation versus protection. Environmental issues in Nigerian development. Evans Brothers, Ibadan

Olsen S, Sommers L, Page A (1982) Methods Soil Anal Part 2:403-430

Ozcan O, Musaoglu N, Seker DZ (2012) Environmental impact analysis of quarrying activities established on and near a river bed by using remotely sensed data. Fresenius Environ Bull 21(11):3147-3153

Sauro U (1993) Human impact on the karst of the Venetian Fore-Alps, Italy. Environ Geol 21(3):115-121. https://doi.org/10.1007/BF00775294

Sheoran V, Sheoran A, Poonia P (2010) Soil reclamation of abandoned mine land by revegetation: a review. Int J Soil Sediment Water 3(2):13

Shrestha RK, Lal R (2008) Land use impacts on physical properties of 28 years old reclaimed mine soils in Ohio. Plant Soil 306(1):249-260. https://doi. org/10.1007/s11104-008-9578-4

Shrestha RK, Lal R (2011) Changes in physical and chemical properties of soil after surface mining and reclamation. Geoderma 161(3):168-176. https:// doi.org/10.1016/j.geoderma.2010.12.015

Singh A, Raghubansh A, Singh J (2002) Plantations as a tool for mine spoil restoration. Curr Sci 82(12):1436-1441

Sinha RK, Pandey DK, Sinha AK (2000) Mining and the environment: a case study from Bijolia quarrying site in Rajasthan. India. Environ 20(3):195203. https://doi.org/10.1023/A:1006795529201

Tanko A (2007) Environmental concerns, assessment and protection procedures for Nigeria's oil industry. Centre for development studies and the school of Geography, Geol Environ Sci, BUK, Nigeria, 1.

Wheater CP, Cullen WR (1997) The flora and invertebrate fauna of abandoned limestone quarries in Derbyshire, United Kingdom. Restorat Ecol 5(1):77-84. https://doi.org/10.1046/j.1526-100X.1997.09708.x

WOARD. (2011). Woreda Laelay Maychew office of agriculture and rural development annual report, Axum.

Zhen Q, Ma W, Li M, He H, Zhang X, Wang Y (2017) Reprint of "Effects of vegetation and physicochemical properties on solute transport in reclaimed soil at an opencast coal mine site on the Loess Plateau, China". Catena 148:17-25. https://doi.org/10.1016/j.catena.2016.09.012

Ziaul S, Pal S (2016) Suitability assessment for selecting new sites for installing water service centres within english bazar municipality, Malda, West Bengal. J Settlements Spatial Plann 7(2):167-178

\section{Publisher's Note}

Springer Nature remains neutral with regard to jurisdictional claims in published maps and institutional affiliations. 